\title{
EXPRESSION OF SOCIAL SMILE OF PRE-TERM INFANTS WITH AGE ADJUSTED
}

\author{
Raquel Costa Albuquerque ${ }^{1}$, Heloisa Gacheggi Ravanini Gardon Gagliardo², \\ Andréa de Souza Lima Barbosa ${ }^{3}$
}

\begin{abstract}
\section{Objective:}

To evaluate and compare the expression of the social smile of infants born preterm, with chronological age and corrected in order to provide more reasons for the effect of neurological maturation in this population. Method: This was an analytical, cross-sectional descriptive which saw the answer as to the behavior of the social smile in a cohort of premature infants in the third month of chronological age and corrected. To evaluate the expression of social smile, we used the Method of Assessment of Visual Infants. Results: It was found that, of 105 preterm infants evaluated, 75 (71.43\%) responded positively to evidence of social smile on chronological age, while $99(94.29 \%)$, corrected age ( $p$ $0.001 \hat{A}$ ) . Conclusions: The expression of the social smile in infants born preterm, to be performed with the correction of gestational age allows these infants to express their real abilities.
\end{abstract}

Key words: smile, facial expression, premature, infant development, infant care.

\section{INTRODUCTION}

Smiling is a psychosocial activity that begins in the first months of life and is one of the infant's means of communication. sorriso é uma habilidade psicossocial que se inicia nos primeiros meses de vida do lactente e uma das formas de comunicação. It triggers confidence and affection, as well as being an expression that strengthens the positive relations between the child and the adult. It may occur soon(?) after birth, spontaneously and involuntarily, as a result of the development of the activity of the central nervous system ${ }^{1,2}$

The infant's competence in recognizing the facial expression of emotion during the first two years of life were investigated between 2001 and 2008. The results of those studies showed that only after the fourth month of life was the infant capable of distinguishing the emotional content of the expressions related to pleasure or displeasure ${ }^{2-}$ ${ }^{4}$ There are other studies, however, which report that the smile in full-term infants begins in the second month of life, in reply to the smile of the adult ${ }^{5,6}$.

There are many possible causes for delay in infants' psychosocial development. The absence of the expression of the smile is, one of them. This may hinder the development of the social link between the child and its parents. Further, the low frequency of the social smile may also be associated with other situations such as social isolation, difficulties' in grasping things, linguistic delays and sensorial difficulties ${ }^{7-9}$

At the present time, both in developed and developing countries, an increase in the survival rate of preterm newborn is being observed. The neonatal complications arising from various risk factors damage, in greater or lesser degree, the normal course of the neurological and intellectual development of these newborn children. Such alterations may result in functional deficits, leading to cognitive, motor and behavioral problems, with repercussions in the activities of daily life and in the interaction between the infant and the adult ${ }^{10}$.

Thus, the purpose of this study is to assess and compare the expression of the social smile of preterm infants at their chronological and corrected age.

\section{METHODS}

This is a descriptive, analytical, crosssectional study undertaken to ascertain the

\footnotetext{
1 Departamento de Terapia Ocupacional - Universidade Federal de Pernambuco - Av dos Reitores S/N - Recife (PE).

2 Heloisa Gacheggi Ravanini Gardon Gagliardo - Faculdade de Ciências Médicas - UNICAMP - Campinas (SP).

3 Andréa de Souza Lima Barbosa - Universidade Federal de Pernambuco - Av dos Reitores S/N - Recife - (PE).

FINANCING: CNPq - EDITAL UNIVERSAL 2006 - PROCESSO 483947/2006-7

Corresponding Author: raquel.albuquerque@terra.com.br
}

Suggested citation: Albuquerque RC, Gagliardo HGRG, Barbosa ASL. Expression of social smile of pre-term infants with age adjusted. Journal of Human Growth and Development 2013; 23(3): 318-321

Manuscript submitted Oct 29 2012, accepted for publication Jul 202013. 
response in terms of the social-smile behavior of a cohort of premature infants during the third month of their chronological and corrected age. The correction of gestational age was made by subtracting from 40 weeks the gestational age in weeks to birth ${ }^{11}$.

The recruitment and the assessment of the sample population was undertaken at the Instituto de Medicina Integral Professor Fernando Figueira - IMIP, during the period from 2007 to August 2009.

This study sample consisted of 105 infants, born between 28 and 36 weeks and six days of pregnancy, with Apgar equal to or greater than 7 at the fifth minute, with no neurological or ophthalmological alteration and no congenital malformation and/or genetic syndrome and who had no need of special care.

The Method for the Assessment of the Visual Behavior of the Infant (Método de Avaliação da Conduta Visual de Lactente) was used for the assessment of the infants. This method consists of a sequence of ten tests to assess and qualify the visuomotor behavior (Illustration 1). A red ring of $12 \mathrm{~cm}$ diameter, suspended by a cord was used, with the face of the examiner as the instrument to elicite the infant's response ${ }^{5}$.

In this study, test 3 - smile on social contact - was used. It should be made clear that the Method for the Assessment of Visual Behavior was applied to all the infants in its entirety, to ensure that the visual reponses were present in all of them and that, therefore, there was no visual impediment to the expression of the social smile.

The Method for the Assessment of Visual Behavior presents a detailed description of the procedures for the application of each test. The procedures related to the application of Test 3 smile on social contact, are described below. The smile as response to social contact. Position of the child - supine. Position of the examiner - directly facing the child. Instrument / stimulus - the examiner's face. Application - lean forward until your face is $30 \mathrm{~cm}$ above and directly in line with that of the child. Smile and move your head four or five times: observe the response and then speak gently to the child. Repeat this three times. Response - smile or make a noise in response to any of the stimuli.

Each infant was assessed individually, in the presence of its parents or legal guardians. The assessment was carried out by an examiner who had been previously trained and with him there was an observer whose function was to record and check the data. After the application of the test, the record of the examiner was compared with that of the observer to ascertain any possible differences of interpretation.

The data were processed by the Statistical Package for Social Sciences (SPSS) program, version 13 (SPSS Inc., 2003 ${ }^{\circledR}$ ), with double entry to avoid possible typing errors. Frequency distribution was undertaken for the descriptive analysis of the variable studied. McNemar's Test was applied to verify, by the comparison of the chronological and corrected ages, possible differences in the responses of social smile behavior,

This study was approved by the thics in Research Committee of the Instituto de Medicina Integral Professor Fernando Figueira - IMIP, under protocol n 1093.

\section{RESULTS}

A total of 105 infants ( 46 boys and 59 girls), with an average gestational age of $34.5+1.7$ weeks , varying between 34 and 36 weeks and six days' gestational age in $81.9 \%$. Apgar equal to or greater than 9 was presented by $51.4 \%$ of the infants.

The data obtained in the assessment of the expression of social smiling of the preterm infants, with chronological and corrected age, as also the results of the statistical analysis of the comparison between the ages are presented in Table 1.

Table 1: Distribution of the responses on testing smiling on social contact in the third month of chronological and corrected age of 105 preterm newborn

\begin{tabular}{lccccc}
\multicolumn{5}{c}{ Chronological Age } & \multicolumn{3}{c}{ Corrected Age } & \\
& $n$ & $\%$ & $n$ & $\%$ & p* \\
Yes & 75 & 71.43 & 99 & 94.29 & \\
SSC & & & & & $p<0.001$ \\
No & 30 & 28.57 & 6 & 5.71 &
\end{tabular}

SSC - Smile on social contact

* McNemar's Test.

\section{DISCUSSION}

The analysis of the results of this study presented statistically significant values as regards social smiling when the data obtained from the assessment of a group of preterm infants with and without correction of gestational age, were compared. A greater frequency of positive response for the assessment of the smile was found when corrected gestational age was considered.

During its first months of life, the infant begins to undergo changes as regards its ability to express itself. The first of them occurs at about the second and third months, when one observes the occurrence of the social smile and changes in the quality of the child's interaction with the adult ${ }^{1-3}$.

Some of these changes occur because the brain is continually adapting to the processing of behavioral demands. . This adaptation is rapidly achieved by the modulation of the way in which the functioning of the cortical circuits which control the 
way in which information is transmitted, transformed and recorded, function ${ }^{12}$.

Between the end of the first and the third month of life, the infant looks into the eyes of the person with whom if is interacting. Generally, it looks into the eyes of the person who is interacting with it and almost immediately smiles. This pattern is perceived subjectively by the adult as the child's first truly social smile. It is in this situation that the social smile becomes usual and spoken sounds start to be directed to, others ${ }^{8,10}$.

That the psychosocial ability to smile should arise there need to be growth, development, and the maturing of the central nervous system in association with the experience of the environment and affective experience, especially of the motherbaby relationship ${ }^{12,13}$.

Its importance as a mark of infant development is noteworthy because the social smile stimulates the socialization of the child and promotes its cognitive development. It, further, stimulates the infant's learning by virtue of its adaptive responses to the stimuli offered, whether by means of another person's smile or through play $^{14}$.

Parallel to the adequate conditions for development, prematurity has been under discussion in the literature as a risk factor for both physical and psychic development in so far as it exposes the child to adverse conditions capable of influencing it also in its response to the social smile ${ }^{15,16}$.

As expounded above, it is found that the appearance of the social smile is influenced by the visual contact that the infant establishes with the adult and is, therefore, an ability mediated by the vision. It has been known since the 1980s that visual experience affects the formation of the neuronal network and that deprivation of this stimulus at critical points in the brain's development affects the development of the vision ${ }^{17,18}$.

One has been able to observe more recently in the literature a growing interest in investigation into the influence of extrauterine visual experience in preterm infants on visual behavior. A study which made use of the Visual Evocative Potential (VEP) to assess preterm infants' vision concluded that the extrauterine experience does not seem to accelerate the process of myelization of the visual pathway, however, the extrauterine visual experience does accelerate the shape of the development of particular VEP waves which emerge on the basis of the development of the visual cortex. Further, the authors enquire if this accelerated maturation of the form of the VEP wave in the preterm period might not be related to the greater cortical visual functioning and, therefore, have an effect on visual behavior in infancy. They thus recommend that longitudinal studies on infants should be continued ${ }^{19,20}$.

Other researchers report that the advances made in electrophysiology and imaging techniques provide opportunities at the present time to sound out with greater sensitivity the impact of prematurity on visual development. They say that there is a need to enlarge our knowledge of preterm infants' visual function so as better to understand the positive or negative effects of premature birth on visual development, seeing that this is important in itself as well as because it reflects the general neurological function ${ }^{21,22}$.

Although there is no consensus as to the correction of age for the obtaining of trustworthy responses in the assessment of visual abilities, researchers have undertaken a study in which they concluded that preterm infants, when assessed without the correction of gestational age, were far from presenting the expected response for the visual behavior assessed. Further, those same researchers also suggest and recommend that, when one assesses the visual abilities of preterm infants, the gestational age should be corrected ${ }^{23}$.

In view of the mediation of sight in the ability to smile on social contact, the results of this study corroborate the results of previous studies which recommend the correction of gestational age to guarantee a more precise diagnosis during the first years of life ${ }^{24}$.

The obtaining of statistically significant values $(p<0.001)$ in this present study in the comparison of infants' responses both with and without correction of gestational age demonstrates that when its age is corrected the child is permitted greater opportunity to express its abilities and its behavioral repertoire, respecting its rate of neurological maturation.

Thus, when one does not take the corrected age into consideration as a parameter in the assessment of the preterm infant's ability to smile on social contact, this may be sufficient to classify this population of infants, erroneously, as being at a developmental disadvantage.

Precocious exposure to visual stimuli does not accelerate the expression of behavior. Thus, it may be concluded that the assessment of behavioral abilities mediated by the vision, as, for example, the expression of the social smile in preterm infants, when undertaken with the correction of gestational age permits the infants to express their real abilities.

Box 1: Checklist for the Assessment of Infants' Visual Behavior

\section{Tests}

\section{Response}

Yes No

1. Visual fixation

2. Eye contact with examiner Contato de olho com o examinador

3. Smile as response to social contact Sorriso como resposta ao contato social

4. Following horizontal vision

5. Following vertical vision

6. Visual exploration of surroundings

7. Visual exploration of the hand

8. Increase of the movement of the upper members on visualizing an object

9. Reaching out for the object visualized

10. Presence of ocular signals (signs?) 


\section{REFERENCES}

1. Otta E, Sarra S. Um estudo sobre o sorriso e o riso em crianças de quatro a cinco anos. Psicol USP. $1990 ; 1(1): 13-24$.

2. Lopes DV, Martinez FE, Linhares MBM. Comportamento exploratório de bebês nascidos prétermo em situação de brincar. Est Psicol. 2008; 13(4):34-7.

3. Moura ML, Ribas AFP, Seabra KC, Pessôa LF, Nogueira SE, Mendes DMLF et al. Interações mãe-bebê de um e cinco meses: Aspectos afetivos, complexidade e sistemas parentais predominantes. Psicol Reflex Crít, 2007; 21(1): 66-73.

4. Alfaya C, Schemann L. Sensibilidade e aleitamento materno em díades com recém-nascidos de risco. Est Psicol. 2005; 10(2):279-85.

5. Gagliardo HGR, Gonçalves VM, Lima MCMP. Método para conduta visual de lactentes. Arq Neuropsiquiatr. 2004; 62:300-6.

6. Ruas TCB, Rivanini SG, Martinez CS, Gagliardo HR, Françoso MFC, Rim PHH. Avaliação do comportamento visual de lactentes no primeiro e segundo meses de vida. Rev Bras Crescimento Desenvolv Hum. 2006; 16(3):1-8.

7. Lopes RMF, Nascimento RFL, Souza SG, Mellet LG. Desenvolvimento cognitivo e motor de crianças de zero a quinze meses: Um estudo de revisão. [Online]. Portal dos Psicólogos, 1:1-15, 2010. Disponível em: http://www.psicologia.pt/ artigos/textos/A0529.pdf.

8. Beline AEG, Fernandes FDM. Olhar de bebês em desenvolvimento típico: Correlações longitudinais encontradas. Rev Soc Bras Fonoaudiol. 2007; 12(3):165-73.

9. Strathearn L, Li J, Fonaqy P, Montaque PR. What's in a smile? Maternal brain responses to infant facial cues. Pediatrics. 2008; 122(1): 13-5.

10. Zomignani AP, Zambelli HJL, Angêla MRG. Desenvolvimento cerebral em recém-nascidos prematuros. Rev Paul Pediatr. 2009; 27: 198-203.

11. Pessoto MA, Marba STM. Avaliação clínica do recém-nascido. In: Ribeiro MVLM, Gonçalves VMG. Neurologia do desenvolvimento da criança. Rio de Janeiro: Revinter; 2006. p. 145-161.
12. Harris KD; Thiele A. Cortical state and attention. Nat Rev Neurosci. 2011; 12(9): 509-23.

13. Bergamasco NHP. Expressão facial como acesso à consciência do recém-nascido. Psicol USP. 1997; 8(2): 17-9.

14. Goulart, AL; Morais, MB de; Kopelman, BI. Impacto dos fatores perinatais nos déficits de crescimento de prematuros. Rev. Assoc. Med. Bras., São Paulo. 2011; v.57, n.3.

15. Ferreira, APA; Albuquerque, RC; Rabelo, ARM; Farias, FC de; Correia, Barros, RC de; Gagliardo, Gardon, HGR; et al. Comportamento visual e desenvolvimento motor de recém-nascidos prematuros no primeiro mês de vida. Rev bras crescimento desenvolv Hum. 2011; vol.21, n.2, pp. 335-343.

16. Van Hof-van Duin J, Mohn G. The development of visual acuity in normal fullterm and preterm infants. Vision Research. 1986; 26: 909-16.

17. Wiesel TN. Postnatal development of the visual cortex and the influence of environment. Nature. 1982; 299: 583-91.

18. Tsuneishi S, Casaer P. Effects of preterm extrauterine visual experience on the development of the human visual system: a flash VEP study. Developmental Medicine \& Child Neurology. 2000; 42: 663-668.

19. Madan A, Jan JE, Good WV. Visual development in preterm infants. Developmental Medicine \& Child Neurology. 2005; 47: 276-280.

20. Braddick O, Atkinson J. Development of human visual function. Vision Research. 2011; 51:15881609.

21. Romeo DM e cols. Visual function assessment in late-preterm newborns. Early Human Development. 2012; 88:301-305

22. Ricci, D e cols. Early assessment of visual function in preterm infants: How early is early? Early Human Development. 2010; 86: 29-33.

23. Kayed NS, Farstad H, Van Der Meer AL. Preterm Infants timing strategies to(?) optical collisions. Early Hum Dev. 2008; 84(6):381-8.

24. Albuquerque RC, Gagliardo HGRG, Lima ACVMS, Guerra MQF, Rabelo ARM, Cabral JE. Comportamiento visuomotor de lactantes pretérmino en el primer mes de vida: Comparación entre las edades cronológica y corregida. Rev Neurol. 2009; 48(1):13-6. 